\title{
PREVENTION OF CARDIOVASCULAR RISK FACTORS IN POSTMENOPAUSAL WOMEN RECEIVING TRANSDERMAL HORMONAL REPLACEMENT THERAPY
}

\section{ZAPOBIEGANIE SERCOWO-NACZYNIOWYM CZYNNIKOM RYZYKA U KOBIET POMENOPAUZALNYCH OTRZYMUJĄCYCH PRZEZSKÓRNĄ HORMONALNĄ TERAPIĘ ZASTĘPCZĄ}

\author{
Krzysztof Sieja ${ }^{1(\mathrm{~A}, \mathrm{~B}, \mathrm{C}, \mathrm{D}, \mathrm{E}, \mathrm{F}, \mathrm{G})}$ \\ ${ }^{1}$ University of Szczecin, Department of Health Education Faculty of Physical Culture \\ and Health Promotion, Poland
}

Authors' contribution Wkład autorów: A. Study design/planning zaplanowanie badań B. Data collection/entry zebranie danych C. Data analysis/statistics dane - analiza i statystyki D. Data interpretation interpretacja danych E. Preparation of manuscript przygotowanie artykułu F. Literature analysis/search wyszukiwanie i analiza literatury G. Funds collection zebranie funduszy
Tables: 0

Figures: 0

References: 30

Submitted: 21.01.2016

Accepted: 01.02.2016

\begin{abstract}
Summary
Postmenopausal women have higher risks and incidence of hypertension and cardiovascular disease (CVD) compared to premenopausal. In Women's Health Initiative (WHI) studies restricted to younger postmenopausal women show that initiation of hormonal replacement therapy (HRT) closer to menopause reduced the risk of CVD. The aim of the study was the evaluation of the actual state of knowledge connected with the influence on transdermal hormonal replacement therapy (HRT), in early postmenopausal women, on the concentrations of sex hormones, lipids, coagulation markers and other parameters associated with cardiovascular risk. In women receiving transdermal hormonal replacement therapy, the significant decrease of concentrations of TC, LDL-C, lipoprotein (a), homocysteine, fibrinogen, C-reactive protein, and the increase of concentrations of HDL-C, PC-protein, PS-protein and antithrombin III in blood serum were found. This regimen did not increase arterial blood pressure.

Conclusions: 1 . In early postmenopausal women receiving transdermal hormonal replacement therapy the levels of estradiol, estrone and progesterone in blood serum assured the optimal concentration of these hormones. -2 . Long-term transdermal hormonal replacement therapy in early postmenopausal women resulted in beneficial effects on the concentration of sex hormones, lipids, coagulation markers and other parameters associated with cardiovascular risk. - 3. Favourable biophysical and biochemical results of the long - term transdermal hormonal replacement therapy, indicate that the presented mode of hormonal treatment is the procedure of choice in the prophylaxis and treatment of early postmenopausal women with the biochemical risk factors of arteriosclerotic vascular diseases.
\end{abstract}

Keywords: postmenopause, transdermal hormone replacement therapy, estradiol, lipids, risk factors, cardiovascular diseases

\section{Streszczenie}

Okres pomenopauzalny u kobiet cechuje się większym ryzykiem i częstością nadciśnienia tętniczego i schorzeń sercowo-naczyniowych w porównaniu z okresem premenopauzalnym. W badaniu pod nazwa Women's Health Initiative (WHI) wykazano, że rozpoczecie hormonalnej terapii zastępczej we wczesnym okresie pomenopauzalnym redukuje ryzyko schorzeń sercowonaczyniowych u kobiet. Celem pracy była ocena aktualnego stanu wiedzy związanego z wpływem przezskórnej hormonalnej terapii zastępczej (HTZ) we wczesnym okresie pomenopauzalnym na stężenia hormonów płciowych, lipidów, czynniki krzepnięcia krwi i inne parametry związane z ryzykiem sercowo-naczyniowym. U kobiet otrzymujacych przezskórną hormonalna terapię zastępczą stwierdzono istotne obniżenie stężeń TC, LDL-C, lipoproteidy (a), białka C-reaktywnego oraz wzrost stężeń HDL-C, białek PC i PS i anty trombiny III w surowicy krwi. Przezskórny sposób podawania hormonalnej terapii zastępczej nie powoduje wzrostu ciśnienia tętniczego krwi.

Wnioski: 1. Przezskórna hormonalna terapia zastępczą zastosowana we wczesnym okresie pomenopauzalnym zapewnia optymalne stężenia estradiolu, estronu i progesteronu w surowicy krwi. - 2. Długotrwale stosowana we wczesnym okresie pomenopauzalnym, przezskórna hormonalna terapia zastępcza wpływa korzystnie na stężenia hormonów płciowych, lipidów, czynniki krzepnięcia krwi i inne parametry związane z ryzykiem sercowo-naczyniowym. - 3. Korzystne biofizyczne i biochemiczne wyniki stosowania długotrwałej przezskórnej hormonalnej terapii zastępczej wskazują, że przedstawiony sposób leczenia hormonalnego jest procedurą $\mathrm{z}$ wyboru $\mathrm{w}$ profilaktyce i leczeniu kobiet we wczesnym okresie pomenopauzalnym z biochemicznymi czynnikami ryzyka miażdżycowych chorób naczyniowych.

Słowa kluczowe: okres pomenopauzalny, przezskórna hormonalna terapia zastępcza, estradiol, lipidy, czynniki ryzyka, schorzenia sercowo-naczyniowe 


\section{Introduction}

Menopausal hormone therapy (MHT) has confirmed effectiveness in the management of both the vasomotor symptoms (hot flushes and sweating) and their indirect consequences (irritability, nervousness, insomnia, memory and concentration problem) and urogenital atrophy symptoms, which are present in most women in perimenopause and postmenopause as a result of estradiol deficiency. Postmenopausal women have higher risks and incidence of hypertension and cardiovascular disease (CVD) compared to premenopausal [1, 2, 3]. In Women's Health Initiative (WHI) studies restricted to younger postmenopausal women show that initiation of hormonal replacement therapy (HRT) closer to menopause reduced the risk of CVD [4]. HRT has become one of the most controversial topics related to women's health. Moreover the dosage, duration, the type of estrogen and the route of administration all merit consideration when determining the outcome of HRT [5]. Further studies are necessary to develop new hormonal therapeutic strategies to improve the quality of life for women.

The efficiency of hemostatic system is dependent on the occurrence of dynamic equilibrium between blood coagulation and fibrinolysis. The disturbances of this equilibrium may lead to hypercoagulability resulting in cardiovascular diseases [6]. This is connected with coagulation factors excess or deficiency of its inhibitors.

The increased rate of cardiovascular incidents was found in hiperfibrinogenemia, which is connected with other risk factors, such as advanced age, postmenopausal state, inflammation processes, hypertension, diabetes mellitus and dyslipidemia [ 7,8].

In the postmenopausal state the progressing deficit of sex hormones and other hormonal changes induce the disturbances of homocysteine (Hcy), fibrinogen (Fib), C-reactive protein (CRP), lipoprotein(a) (Lp(a)), protein C (PC), protein S (PS) and antithrombin III (AT III) concentrations in blood serum or plasma $[9,10,11,12]$.

In postmenopausal women the increase of total cholesterol ( $\mathrm{T}-\mathrm{CH})$, low density lipoprotein - cholesterol (LDL-CH), triglycerides (TG) and the decrease of high density lipoprotein - cholesterol (HDL-CH) was found [13]. Dyslipidemia is the risk factor of coronary heart disease development, whose incidence in women after 50. is still significantly lower, compared to men, but the prognosis is worse following the deficit of estrogens and the disturbances of hemostatic factors [3]. The sharp rise of coronary heart disease incidence in the postmenopausal women is the most frequent cause of deaths in this period of life [14].

The aim of the study was the evaluation of the actual state of knowledge of the influence of transdermal hormonal replacement therapy (HRT), in early postmenopausal women, on the concentrations of sex hormones, lipids, coagulation markers and other parameters associated with cardiovascular risk.

\section{Discussion}

The concentrations of C-reactive protein (CRP), protein C (PC), protein S (PS) and antithrombin III (AT III) during transdermal HRT were assessed. In the group receiving transdermal HRT, the concentration of CRP was highly significantly decreased after one, 3, and 5 years of therapy. The concentrations of PC, PS and AT III were highly significantly increased after one, 3. and 5. years of therapy compared to the values before treatment [15].

In group receiving HRT systolic blood pressure as well as diastolic blood pressure and BMI remained unchanged during five years of therapy [15].

The classical mode of supplementation of hormones in replacement therapy in postmenopausal women in therapeutic cycle should assure the optimal concentrations of these hormones in blood serum. The hormonal profile was nearly the same as in premenopausal women with physiological menstrual cycle. The concentrations of estrogens during transdermal HRT are optimal (estrone on average between 60 - 80 pg/ml; estradiol, on average, between $50-70 \mathrm{pg} / \mathrm{ml}$ ) and progesterone concentration in the second phase of the therapeutic cycle was on average $8,0 \mathrm{ng} / \mathrm{ml}[16]$.

In the group of women receiving transdermal HRT, the concentration of $\mathrm{E}_{1}$ increased on average by 4.5 -fold and $\mathrm{E}_{2}$ increased by 3 -fold compared to the initial values before treatment [15].

The progressively diminishing physiological activity of ovaries and other endocrine organs leads to the development of dyslipidemia as reflected in the increase of T-CH, TG, Lip(a)) and decrease of HDL-Ch. These changes in lipidogram are risk factors of the development of coronary heart disease [4, 17]. The role of estrogens in the regulation of lipid metabolism is multifactorial. They activate the mono- and triglyceride lipoprotein lipases and phospholipases [18]. Moreover estrogens influence the synthesis of receptors binding these enzymes with vascular endothelium [19]. The supplementation with estrogens of postmenopausal women increases HDL synthesis in liver and decreases of concentrations of TG and LDL-CH in blood serum [18. 20].

In women applying transdermal HRT the significant decrease of TG, LDL-CH and TG concentrations and increases of HDL-CH were found as early as after one year of transdermal HRT with increasing significance after 3 and 5 years of treatment [15]. These results are in accordance with results of other authors [13, 21]. 
The concentration of $\operatorname{Lp}(\mathrm{a})$, which is a major risk factor of cerebral ischaemic, cardiac ischemia and the independent marker of atherosclerosis, tends to increase in the postmenopausal period. In women supplemented with transdermal HRT the Lp(a) concentration in blood serum was observed significant decreased [17]. In the group receiving transdermal HRT the concentrations of Lp(a) were significantly decreased after one, 3 , and 5 years of therapy [15].

In women receiving transdermal HRT significant decrease of homocysteine during the whole therapy was observed [10, 21, 22].

Transdermal hormonal replacement therapies caused significant decrease of fibrinogen (Fib) in blood serum (The Writing Group for the PEPI Trial 1995). Generally, Fib concentration in blood serum increases with age but this increase is smaller in women with hormonal replacement therapy in postmenopausal age [5, 18, 23, 24, 25].

In women supplemented with transdermal HRT the concentration of CRP in blood serum was significantly diminished compared to initial pretreatment values [15]. Estrogen administered transdermal avoids "first-pass effect" which results in the decrease of CRP in blood serum [6].

The increase of AT III was observed in postmenopausal women receiving transdermal HRT [15,26]. According to many studies the influence of hormonal replacement therapies on C and S Proteins and AT III is different [2, $5,6,7,12,18,24,26]$. Some authors noted the increase of protein $C$ and $S[12,20]$ but others observed decrease of these natural coagulation inhibitors [Fishman et al. 2003].

Transdermal HRT increases insulin sensitivity, which decreases the risk of developing the type 2 diabetes and metabolic syndrome [27].

The positive influence of the long - term transdermal hormonal replacement therapy on blood pressure in postmenopausal women was observed. In many studies, favourable effect of long - term hormonal replacement therapy on angiotensin - converting enzyme activity and bradykinin in postmenopausal women was found $[3,7,21]$. The results of studies performed by many authors should be the inspiration to supplementation of transdermal HRT in the prophylaxis of cardiovascular events in postmenopausal women $[4,11,13,19,21,28]$.

The detailed analysis of Women's Health Initiative data reviewed specifically address the timing hypothesis [4]. For hormone therapy initiated soon after menopause versus the therapy started later, the findings demonstrate:

1. Similar null or adverse effects on cardiovascular risk;

2. Similar adverse effects on the risk of stroke and venous thrombosis; and

3. Possibly greater adverse effects on breast cancer risk.

Therefore, Women's Health Initiative data do not support the hypothesis of favourable effects in women starting hormone therapy soon after menopause.

However, a number of observational studies found that women using hormone therapy were at lower risk of cardiovascular disease than nonusers $[14,21,28,29,30]$. The expectations of cardioprotection was chiefly based on data from studies of intermediate biomarkers, such as: lipoprotein, cholesterol levels, blood pressure, insulin levels, and indices of arteriosclerosis. Hence according to Recommendations of the Polish Menopause and Andropause Society: "Randomized clinical trials and observational data as well as meta-analyses provide evidence that standard-dose estrogen-alone menopausal hormonal therapy may decrease coronary heart disease and all-cause mortality in women younger than 60 years of age and within 10 years of menopause. Data on estrogen plus progestogen menopausal hormonal therapy in this population show a similar trend for mortality but in most randomized clinical trials no significant increase or decrease in coronary heart disease has been found" [30].

\section{Conclusions}

1. In early postmenopausal women receiving transdermal hormonal replacement therapy, the levels of estradiol, estrone and progesterone in blood serum assured the optimal concentration of these hormones.

2. Long-term transdermal hormonal replacement therapy in early postmenopausal women resulted in beneficial effects on the concentration of sex hormones, lipids, coagulation markers and other parameters associated with cardiovascular risk.

3. Favourable biophysical and biochemical results of the long - term transdermal hormonal replacement therapy, indicate that the presented mode of treatment is the procedure of choice in the prophylaxis and treatment of early postmenopausal women with the biochemical risk factors of arteriosclerotic vascular diseases. 


\section{References:}

1. Posadny-Małaczyńska A. Menopause as a cardiovascular factor, therapeutic implications of hypertension. Menopausal Rev. 2011; 10(1): 40-44.

2. Kotarski J, Barczyński B, Kwaśniewski W. Menopause hormone therapy and the risk of thrombolic disease. Menopausal Rev. 2011; 10(4): 275-278.

3. Pérez-Klopez FR, Chedraui P, Gilbert JJ, Pérez-Ronco G. Cardiovascular risk in menopausal women and prevalent related co - morbid conditions: facing the post - Women's Health Initiative era. Fertil. Steril. 2009; 64: 1171-1186.

4. Banks E, Canfell K. Invited commentary: hormone therapy risks - and benefits - The Women's Health Initiative findings and the postmenopausal estrogen timing hypothesis. Amer J Epidemiol. 2009; 170: 24-28.

5. Canonico M, Oger E, Plu-Bureau G, Conard J, Meyer G, Lévesque H, et al. Estrogen and Thromboembolism Risk (ESTHER) Study Group, Hormone therapy and venous thromboembolism among postmenopausal women: impact of the route of estrogen administration and progestogens: the ESTHER study. Circulation, 2007; 115: 840-845.

6. Ridker PM. Clinical application of C-reactive protein for cardiovascular disease detection and prevention. Circulation 2003; 107: 363-369.

7. Fisman EZ, Tenenbaum A, Pines A. Arterial hypertension in postmenopausal women. Postgraduate Cardiology (Polish) 2003; 2(3): 38-49.

8. Guimarães DA, Carvalho MG, Cardoso J. Assessment of hypercoagulability markers and lipid levels in postmenopausal women undergoing either oral or transdermal hormone replacement therapy. J. Thrombosis and Thrombolysis 2006; 27: 135-140.

9. Taylor HS. Genetic vs. hormonal factors in lipid metabolism in women. JAMA 2004; 29: 424-425.

10. Ridker PM, Manson JE, Buring Shih J. Homocysteine and risk of cardiovascular disease among postmenopausal woman. JAMA 1999; 281: 1817-1821.

11. Gadomska H, Grzechocińska B, Nowicka B, Marianowski L, Siemińska J. Assessment of the concentrations lipid atherogenic factors and fibrinogen in blood serum in women applying different forms of hormonal replacement therapy in the menopause. Polish Gynecology (Polish) 2001; 72: 1398-1404.

12. Canonico M, Alhenc-Gelas M, Plu-Bureau G, Olié V, Scarabin PY. Activated protein C resistance among postmenopausal women using transdermal estrogens: importance of progestogen. Menopause 2010; 17: 1122-1127.

13. Bingol B, Gunenc Z, Yilmaz M, Biri A, Trias B, Günther H. Effects of hormone replacement therapy on glucose and lipid profiles and on cardiovascular risk parameters in postmenopausal women. Arch Gynecol Obstet. 2010; 281: 857-862.

14. Grodstein F, Manson JE, Stampfer MJ, Wu C, Bared D, Barnabei VM. et al. Hormone therapy and coronary heart disease: the role of time since menopause and age at hormone initiation. J Womens Health (Larchmt) 2006; 15: 35-44.

15. Stanosz M, Stanosz S, von Mach-Szczypiński J, Sieja K, Kościuszkiewicz J, Szczypiński D. et al. Biochemical aspects of modified hormonal replacement therapy in the prophylaxis of atherosclerosis and vascular thrombosis postmenopausal women. Menopausal Rev. 2012; 11(3): 211-219.

16. Stanosz S, Żochowska E, Safranow K, Sieja K, Stanosz M. Influence of modified transdermal hormone replacement therapy on the concentrations of hormones, growth factors, and bone mineral density in women with osteopenia. Metabolism 2009; 58: 1-7.

17. Bayrak A, Aldemir DA, Bayrak T, Corakci A, Dursun P. The effect of hormone replacement therapy on the levels of serum lipids, apolipoprotein A1, apolipoprotein B and lipoprotein (a) in Turkish postmenopausal women. Arch Gynecol Obstet. 2006; 274: 289-296.

18. Ushoda M, Makita K, Takamatsu K, Horigucki F, Aoki D. Serum lipoprotein (a) dynamics before / after menopause and long - term effects of hormone replacement therapy on lipoprotein (a) levels in middle aged and older Japanese women. Horm Metab Res. 2006; 38: 581-586.

19. Mikkola TS, Clarkson TB. Estrogen replacement therapy, atherosclerosis, and vascular function. Cardiovasc Res. 2002; 53: 605-619.

20. Suk Danik JS, Rifai N, Buring JE, Ridker PM. Lipoprotein (a), hormone replacement therapy, and risk of future cardiovascular events. J. Am Coll Cardiol. 2008; 52: 124-131.

21. Cuadros JL, Fernández-Alonso AM, Chedraui P, Cuadros ÁM. Metabolic and hormonal parameters in post menopausal women 10 years after transdermal oestradiol treatment, alone or combined to micronized oral progesterone. Gynecol Endocrinol. 2011; 27: 156-162. 
22. Steed MM, Tyagi SC. Mechanisms of cardiovascular remodeling in hyperhomocysteinemia. Antioxid Redox Signal. 2011; 15(7): 1927-1943.

23. Borgfeldt C, Li C, Samsioe G. Low - dose oral combination of 17 beta-estradiol and norethisterone acetate in postmenopausal women decreases factor $\mathrm{V}$, fibrinogen, antithrombin and plasminogen activator inhibitor -1. Climacterium 2004; 7: 78-85.

24. Bonduki CE, Lourenc DM, Motta E, Soares Jr JM, Haider MA, Barcut EC. Effect of estrogen-progestin hormonal replacement therapy and blood coagulation and fibrinolysis in postmenopausal women. Clinics (San Paulo) 2007; 62: 553-560.

25. Canonico M, Oger E, Plu-Bureau G, Conard J, Meyer G, Lévesque H, et al. Estrogen and Thromboembolism Risk (ESTHER) Study Group, Hormone therapy and venous thromboembolism among postmenopausal women: impact of the route of estrogen administration and progestogens: the ESTHER study. Circulation, 2007; 115: 840-845.

26. Połać I, Borowiecka P, Stetkiewicz T, Nowak P. Hemostatic changes associated with menopausal hormone therapy. Comparison of transdermal and oral administration. Menopausal Rev. 2012; 11(2): 146-150.

27. Mauvais-Jarvis F, Clegg DJ, Hevener AL. The role of estrogens in control of energy balance and glucose homeostasis. Endocr Rev. 2013; 34: 309-338.

28. Bińkowska M, Jakiel G. Menopausal hormone therapy: transdermal route of administration. Menopausal Rev. 2012; 11(4): 281-286.

29. Rossouw JE, Prentice RL, Manson JE. (2007). Postmenopausal hormone therapy and risk of cardiovascular diseases by age and years since menopause. JAMA 2007; 297(13): 1465-1477.

30. Bińkowska M, Dębski R, Paszkowski T, Sendrakowska M, Zgliczyński W. Guidelines for menopausal hormonal therapy. Recommendations of the Polish Menopause and Andropause Society - state of knowledge as of December 2013. Menopausal Rev. 2014; 13(1): 1-12. 